\title{
Russia's Portrayal in the Mirror of International Mass Media: The Role of Cultural Context
}

\author{
Olga B. Maximova ${ }^{1}$ \\ ${ }^{1}$ Peoples' Friendship University of Russia (RUDN University), Moscow, Russian Federation \\ Correspondence: Olga B. Maximova, Peoples' Friendship University of Russia (RUDN University), Moscow, \\ Russian Federation. E-mail: maximova_ob@pfur.ru
}

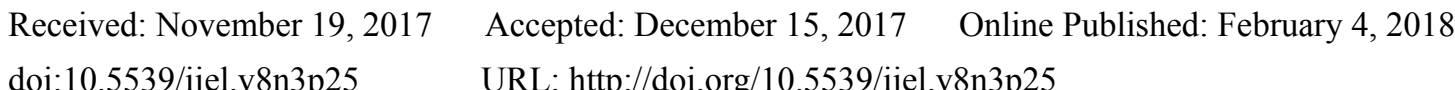

doi:10.5539/ijel.v8n3p25 URL: http://doi.org/10.5539/ijel.v8n3p25

\begin{abstract}
The analysis of cultural context in media texts can contribute to understanding how national images are constructed in the international media discourse. The image of a country is better understood by the audience of another country when it is introduced through familiar cultural concepts and well-known experiences so that specific, culture-bound elements of the other culture are brought closer to the target audience.

The research provides linguo-cultural analysis of Russia's portrayal in political media discourse in English-speaking countries drawing on the approach to political discourse as the process of production and interpretation of a text in meaningful political, social and cultural context.

The study is aimed at exploring British and U.S.A. mass media to reveal typical features of the English-language political discourse concerning Russia and to find out how Russia's image is constructed. In the course of the study we examined culture-bound lexicon in texts of various genres of political discourse in mass media focusing on Russia. Further, the use of Russian culture-bound items without translation in British and American mass media was analyzed, and such items were classified into categories according to their contextual functions.

The results indicate that Russia is deeply integrated into the cultural context of the English-speaking audience; it can be said that Russia's image in the Anglophone political media discourse is outlined with the aid of various cultural-bound associative, connotative and metaphorical links which are familiar for native readers and serve them as a bridge facilitating their understanding and interpretation of Russian culture.
\end{abstract}

Keywords: cultural context, cultural representation, political discourse, mass media, culture-bound elements, background knowledge, linguo-cultural analysis, discourse analysis, Russia's image

\section{Introduction}

The studies of national images created by international media are gaining in importance due to increasing intercultural communication in the contemporary global society, which may be seen in interrelated discourses and social practices through which cultural meanings and representations are produced, consumed and interpreted. Mass media are believed to serve as a platform for such interaction, that is why it is very important to gain insight into what is going on in this sphere, to obtain a clear and precise understanding of its inner workings, that is, to develop an adequate procedure to analyze one country's image construction (e.g., the image of Russia) in the political media discourse of other countries and cultures. Due to the global spread of English the analysis of mass media coverage in the English-speaking countries is of particular importance as they could have a major impact in setting the media agenda for the global world.

We believe that the study of the cultural context in media texts, such as news reports, analytical texts and blogs united by their single focus on Russia, can contribute to understanding how Russia's image is modelled and constructed in the mirror of political discourse of international mass media.Cultural-bound elements of the "other" culture are better understood by the audience when they are introduced through familiar concepts and well-known experiences in accordance with "proximization strategies" which are intended to bring the reality closer to the audience (Cap, 2013; Kopytowska, 2015, p. 308) and provided with algorithms of their interpretation. Therefore, it stands to reason that the analysis of cultural context can provide an opportunity to construe all the elements of the country's image, adequately decode them and interpret their meaning exposing authors' intentions and revealing cultural-bound patterns of readers' perception. 


\section{The Background of the Study}

So far, there has been a number of studies providing insight into Russia's image perception in the West (Feklyunina, 2008; Macgilchrist, 2011) including Russia's portrayal in the political discourse in the media (Belova, 2016; Moscovici, 2012; Solopova \& Ilyushkina, 2017; Teleshova \& Denisova, 2015; Tsygankov, 2016).

Although the scholars are unanimous that political and media discourses are strongly ideologically motivated and representations of Russia reflecting national stereotypes prevail in international mass media coverage (Chudinov, 2001; Sokolova \& Koptyaeva, 2015; Kabel, 2017; Vraciu, 2012), they still lack information on discursive strategies and linguo-cultural means for Russia's image construction in different countries. There is also no unity among researchers on the degree of stereotypization of Russia's portrayal at various levels and domains of the political media discourse. Moreover, there is still little consensus on the contribution of media texts of various genres and sub-genres (e.g., news reports, editorials, comment and opinion, review, political blogs) into the construction of Russia's image.

The analysis of literature has prompted the author to advance a hypothesis that the study of cultural context can be quite useful to understand how the image of Russia is constructed in political media discourse in accordance with cultural-bound perception patterns of English-speaking readers.

In such context the questions to be examined can be put like this: Which features are typical for English-language media to convey culture-bound information about Russia? Which linguo-cultural means are used to construct the image of Russia in different domains of political discourse?

\section{Methodology}

The research work is aimed at linguo-cultural analysis of Russia's portrayal in political media discourse in Great Britain and the U.S.A. drawing on the approach to political discourse as the process of production and interpretation of a text in meaningful political, social and cultural context (Fairclough, 2001).

\subsection{Data Collection}

The studies of culture-bound elements in British and American news-related, analytical texts and blogs we have undertaken to identify particular national and cultural traits have been primarily focused on mass media texts addressing a native reader and concerning the ongoing events in domestic and foreign policy activities of the Russian Federation. These texts were found on leading British and American online newspapers and news sites by keyword queries (or by tags when browsing through the blogs of newsmen or political analysts). The data was provided by newspaper texts of three types: news reports, analytical texts (e.g., editorials, comment and opinion) and blogs. We selected 20 news-related items, 20 analytical texts and 20 blog posts from British and American online newspapers (Note 1). The keywords and tags we used to select the texts and blogs for our analysis were: "Russia", "Russian", "the Russians".

The news agencies the Times, the Guardian, the Daily Telegraph, the Independent, the New York Times and the New York Post, were selected for our study because of their national and international presence in news coverage. As such, these news agencies could have a major impact in setting the media agenda for the Western world. Moreover, they are the largest news agencies in Western Europe and in the U.S.A. The period under analysis is 2010-2012.

\subsection{Research Procedure}

We chose the mixed methods research design, which included the combination of methodologies of discourse analysis (Dijk, 1988; Dijk, 2001; Dijk, 2006; Fairclough, 2001) and content analysis within the framework of linguo-cultural approach (Dobrosklonskaya, 2008). Our main purpose was to study British and American mass media to reveal the typical features of the English-language political discourse concerning Russia and to describe how Russia's image is constructed. Thus, mixed methodology can be considered relevant for this purpose.

We applied the multi-level classification scheme proposed by Dobrosklonskaya, according to which certain elements of a text may be involved in cultural context at denotative, connotative, associative and metaphorical levels (Dobrosklonskaya, 2008, p. 234). The application of the multi-level classification seems relevant for our research due to the following reasons. Firstly, this classification is comprehensive: any culture-bound element of the text can be attributed to one of the levels. Secondly, this classification is not reducible to one-dimensional linear ranking of culture-bound units; it is complex and multidimensional. This feature seems essential to be applied to online texts, such as political blogs on news websites, characterized by non-linearity and openness (Maximova \& Egorova, 2016, p. 293).

In the course of the linguo-cultural analysis we selected a sample of culture-bound lexical elements with 
culturally specific algorithms of interpretation which are involved in cultural context. It is worth mentioning here that such culture-bound lexical elements can carry connotative, associative and metaphoric meanings, their interpretation often implies expressive and emotional involvement as well as attitude, which to some extent can explain their wide application in political discourse.

For the purpose of our research we identified culture-bound elements in texts of various genres of political discourse in mass media (news-related, analytical texts and blogs of British and American mass media) focusing on one common topic-Russia. Then, the selected lexical units were distributed into different levels of cultural context according to the classification by Dobrosklonskaya: denotative, connotative, associative and metaphorical levels.

Further, we carried out the analysis of Russian culture-bound lexicon, i.e., words of Russian origin relating to Russian socio-cultural and historic experience and realities which are used in British and American mass media discourse without translation. In addition to the quantitative analysis of Russian culture-bound lexicon in different domains of British and American political discourse on Russia we analyzed their contextual functions and offered their classification into categories in line with the conducted linguo-cultural analysis.

There is a very important issue here concerning the study of cultural realities expressing Russian national specificity because such "untranslatable terms" are often used in national mass media to create a stereotypical (although bright and colourful) image of phenomenon of foreign reality they describe.

As can be seen from the above, the methods of studying Russia's portrayal in British and American political discourse based on the analysis of multi-level cultural context and culture-bound items provide us with an opportunity to get an idea about Russia's image representation in textual as well as in discourse practices of production / consumption of the text, which are in line with the ideas of Critical Discourse Analysis (Fairclough, 1995, p. 56).

\section{Results and Discussion}

In the course of our analysis we found out that national and cultural traits of the English-speaking discourse concerning Russia come up as follows.

First, once the newspaper texts are categorised by their thematic attributes (such as "domestic events" or "world news"), their placement, the selection of words in headlines, etc., evidence of such innate culture-bound perception arises at information structuring level. A point to note here is a very high degree of ethnocentrism in all English-speaking (most notably, American) mass media. An event that has occurred outside the U.S.A or Great Britain has almost no chance to appear on the front page unless it directly affects the interests of those countries.

Accordingly, most of the media texts we have perused (specifically, analytic texts and blogs) either handle the events in Russia in their connection with the political events in the U.S.A and Great Britain, or spotlight the foreign Russian policy from a viewpoint that will always match the interests of the U.S.A or Great Britain.

All in all, everything pertaining to Russian social and political realities refracts through the prism of national and cultural stereotypes shaped among the English-speaking audience and wraps in essentially negative disguise. Such stale air about Russia is over-pressured with snappy and expressive titles meant to steer the reader in the direction most favourable to the author. Let us provide several vivid examples: "Barack Obama is Proving an Embarrassing Amateur in Confronting the Russian Bear", "Good for Mitt Romney, Telling the Truth about Putin's Russian Tyranny", "At Last, the British Parliament Demands Action against Corrupt and Murderous Russian Officials", "Putin's Cold War Politics Will Fail Russia".

Second, cultural context which is "a multi-layer structure of all information of cultural value in the text" (Dobrosklonskaya, 2008, p. 226) is very important for identification of roots, traditions and paradigms of a specific linguo-cultural community. Units of such context are words and phrases marked by their unique cultural identity and directly related to the whereabouts and biography of a particular linguistic community (English-speaking in our case). A key parameter in culture-specific categorisation is background knowledge, a common comprehension of reality by the speaker and by the listener that provides the grounds for communication (Akhmanova, 2004, p. 478), "our familiarity with the context of the text" (Nunan, 1993, pp. 30-31).

\subsection{Cultural Context}

The cultural context in those texts that are thematically related to a linguo-cultural community different from the one of the author and the readers apparently plays two distinct roles. On the one hand, the use of cultural-bound 
elements well known to English readers embeds Russia-related information into the English cultural context and thus assists them in comprehension and interpretation of whatever happens in Russia. On the other hand, such lexical units, in addition to performing their denotative function, enhance the expressiveness and emotionality, and reflect the author's appraisal of the events thereby implementing manipulatory functions.

And this, alongside the abovementioned ethnocentrism, is the reason why cultural-bound units are so rife in Russia-related texts published in the English language (remarkably, in news analytics and blogs). So, let us discuss them in more details basing on the attributes and degree of involvement in the cultural context. Following Dobrosklonskaya, we shall elaborate four levels within the structure of this context, namely, denotative, connotative, associative and metaphorical levels respectively formed by lexical units used to denote facts or artefacts; words and phrases with culture-bound connotations; lexical units with stable associative relations; and text fragments of the national cultural heritage (Dobrosklonskaya, 2008, p. 234).

\subsubsection{Denotative Level}

Units of denotative level are usually proper names. Thus, this group includes the names of renowned politicians (Winston Churchill, Barack Obama, Hillary Clinton), of political parties and movements (the Tories, the Occupy movement), of historical sites (St. Paul's Cathedral) and well-known places (Harrods, Tiffany), and the names involved in social and political spheres (Downing Street, Fleet Street). In addition, this group includes culture-specific aliases (bendy-bus). Such units are often "compressed" (MP, NHS or $Q C$ ), and their use may be governed by what information presentation conventions are in place (e.g., when mentioning the names of current British politicians in the context of British-Russian relations). In certain cases, these units are encoded to reflect the national mentality. For example, proper names in the American mass media are often frivolously replaced with the nicknames of political leaders (recall "the Gipper" stuck for long to R. Reagan after his role in a biographical movie). Finally - every too often, and the more so in bloggers' communications, - culture-bound units are aimed at transferring Russia-specific set-ups to a cultural soil native for the recipient. In this regard, the following excerpt from the paper entitled "What Orthodoxies Would a UK Pussy Riot Bravely Mock? It Could Start with the NHS" by Brendan O'Neil in his blog on the site of conservative British "The Daily Telegraph" may be exemplary. Here, the author draws ironic parallels between the social and political environments in Russia and in the Great Britain:

"And it wouldn't do for a UK Pussy Riot publicly to demand that David Cameron be ousted. There would be nothing radical in that either. Even sections of the Tory Party suggest it. But there are still some orthodoxies that a UK Pussy Riot might colourfully thrash. For example, it could storm into a major hospital and show a metaphorical bum to the NHS."

\subsubsection{Connotative Level}

Much space in the English-world publications about Russia is allocated to lexical units of connotative level that are used to assert the author's opinions and ideas within the cultural landscape. Most importantly, these units comprise elements of the social and political vocabulary (primarily political terms) that make up universal concepts of diverse instrumental political connotations, and capture the essence of domestic world outlook. Such terminology is kindred to the "ideological war of terms," marked by its ideological modality, and handy for the authors when they need to put their intended political and ideological accents. For example, when the events in Syria and the respective Russian stance are discussed, the English-speaking press generally tends to select positive wordings for Syrian opposition groups and their activities (the opposition forces, revolutionaries, uprising) whereas the accents are readily shifted to negative in any critical reviews of the ruling Syrian authorities (Assad's regime, Assad's clan) or when it comes to the attitude of Russian journalists adopting a different viewpoint. An example discussion of such single-sided approach to disastrous circumstances in Syria can be found in the David Blair's blog on "The Daily Telegraph" site entitled as "Rebels or Revolutionaries? The Russian Media's Coverage of Syria's Uprising is a Distorted Reflection of Our Own":

"While the Western media refers to "opposition forces" and sometimes "revolutionaries" fighting Bashar-al-Assad's regime, the Russian media persistently uses the term "povstansy". This has a negative connotation and refers to armed groups trying to overthrow a lawful government."

Now, here is one of the comments to this record:

"Both words "rebel" and "revolutionary" in fact have positive connotations in English, and both are used in the western media to describe the opposition in Syria. The word generally used by Russian media, "povtansy", equates more or less to the English word "insurgents"."

Despite the clear position of both authors, these text fragments expose fairly rudimentary knowledge of the 
Russian word usage. In the Russian language, the word "rebels" is rather positively than negatively coloured, as expressly remarked by the author of the below comment:

"Unlike primitive black-and-white descriptions of the Syrian war in the Western media, the Russian media recognise the complexity of the protest movement. The Russians use a range of terms to describe the government opposition in Syria: opposition (most common), armed opposition, opposition army/militants, regime opponents, rebels, insurgents, local armed defence groups, international terrorist organisations, ordinary jihadists, radical islamists, islamic extremists, Syrian jihad, people's revolution, etc. The term "nовстанцbl» (rebels, insurgents) does not have any negative connotation in the Russian language, it is neutral."

Note that the linguistic negligence corrected above is not due to some formidable obstacles in translation: it is a sheer manifestation of stereotypes concerning Russia and the Russian press, and implying that no Russian mass media is allowed to assume different points of view (including the ones that contradict the official standpoint).

These lexical units of political and analytic connotation we routinely find in sundry media texts have their counterparts at the denotative level that are imbued with connotative meanings by the authors. Following Dobrosklonskaya (2008, pp. 229-230), we attribute them to culture-induced components of the connotative level as well. Hereinafter, we refer to lexical units or compound words of unstable type that bring out extra emotional and expressive flavours most easily understood and consumed by the target audience. Examples may be: "rollercoaster ride in relations" (on the USA-Russia relations), or "a contention of double-decker proportions" (on incessant and resonant disputes as to whether the Russian bus is a suitable place to mount the portrait of Stalin).

\subsubsection{Associative Level}

The next, associative, level of the cultural context is a key to understanding where these native stereotypes of English media unite to create their alleged Russian culture. Every associative level may employ various cultures enhancing the one of the original author of the text (Dobrosklonskaya, 2008, p. 187). Its components are lexical or phraseological units with basically stable associative relations that should match the cultural self of the addressee and can be used in a certain way in news-related articles or blogs about Russia in order to appraise, compare or describe what is going on. Culture-specific units of this level are often used to decipher Russian names that could be unfamiliar to the average foreign reader, e.g., "Mikhail Lomonosov, who is regarded as a Russian Leonardo da Vinci"; "Moscow State University serves the function of Harvard, Oxford and the Massachusetts Institute of Technology all rolled into one"; "the Investigative Committee is Russia's version of the FBI". Besides this, these names are used to create an emphatic or often ironic image with how-do-you-feel-that connotations behind the author's attitude. In the next example taken from "Putin Wins Again. Rebuilding Imperial Russia" by Ralf Peters, a famous American writer and journalist, a definitive concern regarding the Russian support of anti-Iran sanctions is traceable in a peculiar associative chain he devises:

"On Iran, Putin's a savvy old tomcat toying with the Obama mouse. While Moscow's overt, covert and clandestine trade with Tehran continues, Putin does his good-cop/bad-cop routine with President Dmitry Medvedev, keeping hope alive in the White House that, this time, Russia will finally back meaningful sanctions. Sarah Palin will sign on with Code Pink first."

(The New York Post)

What is immediately apparent, an adequate understanding of the above comparison prompts the reader to acquire more or less credible information as to what has been cooked in the backgrounds, by the Republican Party of Sarah Palin declaring that bloody war with Iran followed the Mr. Barack Obama's war threats, or otherwise, by the women's "Code Pink" communities which do protest against the same.

\subsubsection{Metaphorical Level}

Now, the fourth, we call it metaphorical level of cultural context. Our results show that its actual levels seem to activate in analytic texts and blogs as a rule (or in news reports to a lower degree). Its elements may be famous literary quotations, memorised mass media titles, aphorisms or proverbs or by-words, paraphrases of known ideas, sayings, etc. These are different from the associative level as they do require something beyond the well-measured ordinary backgrounds to get an adequate understanding of the events: having acquired a solid image of one or other event, the reader should be capable of obtaining an in-depth knowledge of the texts that have already been deemed as the constituents of their national culture. Our claim is that attaining a high cultural value and reaching such cultural conditionality can only be achieved at this metaphorical layer.

Let us provide some typical examples. The passage given below compares the performance of the feminist punk 
band Pussy Riot to the October Revolution in an elegant paraphrase of John Reed's book title "Ten Days That Shook the World":

"The group's incendiary performance of a "punk prayer" against him inside Moscow's Christ the Saviour cathedral has become one of those moments that crystallise a society's discontents. They were 51 seconds that rocked Russia."

\section{(The Times)}

The next example is about the Russian oligarchs, Boris Beresovsky and Roman Abramovitch, in their outstanding legal case. An allusion to the title of the famous Charles Dickens' novel "A Tale of Two Cities" is made to express the author's attitude to the events:

"But the case is a uniquely Russian one - a tale of greed, political manipulation and deceit in the murky years of Boris Yeltsin's presidency. Abramovich's QC Jonathan Sumption compared 1990s Russia to "medieval England"."

\section{(The Guardian)}

Another discovery would be an article "Putin Wins Again. Rebuilding Imperial Russia", which successfully paraphrased the title of Thackeray's "Vanity Fair," expressing the author's irony concerning Washington nuclear summit and a curious unpopularity of a certain politician whom America used to applaud:

"At this week's Nuclear Vanity Summit (which accomplished nothing) Obama snubbed Georgia's president, Mikhail Saakashvili."

(The New York Post)

Should we comment on anything in the following passage from "The Daily Telegraph"? Perhaps, it's all clear about Russian policies in Syria. What could be added to the Syrian leader's description as a weak-willed regular person belonging to a powerful clan like Fredo Corleone with the majestic yet simple-minded aura of Forrest Gamp to figure out his poor chance to survive:

"When Russia sounds more conciliatory to the Western position, it is to buy more time for Damascus. If Putin has one lament, it is only that Bassel al-Assad, Bashar's smarter older brother, died in a car crash in 1994. Thus was a perfectly good client state entrusted to a combination of Fredo Corleone and Forrest Gump."

Finally, the following article devoted to the parliamentary elections in Russia does perfectly fit in parabolic patterns with its protagonists taken from popular comics and movies:

"The election was about him: Putin wanted the country to acclaim his place as the country's paramount leader, just before it agrees to elect him for what could be another 12 years of power. Having forced a ritual humiliation on Robin (to use the cruel metaphor of the US embassy cables) by getting him to stand up in front of the party congress and propose his rival's nomination for the presidency, Batman needed to fly."

(The Guardian)

\subsection{Cultural-Bound Elements in News Reports, Analytical Texts and Blogs}

The outlined examples as well as the analysis of the selected culture-bound lexical elements provided above show that British and U.S.A. political media discourse is replete with the elements marked by their cultural specificity. Culture-bound information about Russia is organized in a complex multi-level hierarchical structure. The elements have connotative, associative and metaphoric meanings and are provided with algorithms of interpretation through concepts and experiences belonging to native readers' culture so that they are understandable to the English-speaking audience. Thus, Russia-related information is deeply intertwined into the English cultural context.

Having identified culture-bound elements in news-related, analytical texts and blogs of British and American mass media focusing on Russia we distributed them into different levels of cultural context and carried out content-analysis.

The results of our analysis are presented in Table 1 and Table 2. 
Table 1. Russia's coverage in British political media discourse: culture-bound elements

\begin{tabular}{lllll}
\hline & News reports & Analytical texts & Blogs & Total \\
\hline Units of denotative level of cultural context & 8 & 22 & 21 & 51 \\
Units of connotative level of cultural context & 8 & 12 & 16 & 36 \\
Units of associative level of cultural context & 12 & 35 & 41 & 88 \\
Units of metaphorical level of cultural context & 4 & 16 & 33 & 53 \\
Russian culture-bound lexicon & 8 & 8 & 23 & 39 \\
\hline Total & 40 & 93 & 134 & 267 \\
\hline
\end{tabular}

Table 1 shows the differences in distribution of culture-bound elements into different levels of cultural context for news report, analytical and blogger texts of British mass media.

Table 2. Russia's coverage in U.S.A. political media discourse: culture-bound elements

\begin{tabular}{lllll}
\hline & News reports & Analytical texts & Blogs & Total \\
\hline Units of denotative level of cultural context & 10 & 25 & 18 & 53 \\
Units of connotative level of cultural context & 11 & 8 & 14 & 33 \\
Units of associative level of cultural context & 12 & 28 & 38 & 78 \\
Units of metaphorical level of cultural context & 5 & 13 & 27 & 45 \\
Russian culture-bound lexicon & 6 & 12 & 25 & 43 \\
\hline Total & 44 & 86 & 122 & 252 \\
\hline
\end{tabular}

Table 2 shows the differences in distribution of culture-bound elements into different levels of cultural context for news report, analytical and blogger texts of U.S.A. mass media.

Firstly, as it can be seen from Table 1 and Table 2 cultural-bound elements are present both in British and the U.S.A. mass media texts of all genres devoted to Russia.

Secondly, the results presented in Table 1 and Table 2 demonstrate significant differences in the distribution of cultural-bound elements into different levels of the cultural context for news report, analytical and blogger texts in both countries. As it can be seen, analytical texts and blogs are more deeply integrated into the cultural context of the English-speaking audience than news reports: the proportion of culture-bound elements is higher in analytical texts and blogs than in news reports; cultural-bound elements of "deeper" levels of cultural context (associative, connotative and metaphorical) prevail. The results for news reports are significantly different: the proportion of culture-bound items is smaller and they mostly belong to the denotative level.

Next, there is still another consideration which deserves attention. For all the studied types of media texts we observed a relatively small proportion of elements of connotative level irrespectively of the country under consideration. A possible explanation seems to be that such connotative elements not infrequently possess and exhibit characteristics typical for other levels of cultural context-associative and metaphorical levels; therefore, connotative elements were registered as the elements of higher level of cultural context in the course of the analysis.

Finally, it should be pointed out that the differences between the countries, i.e., the U.S.A. and Great Britain in the distribution and number of culture-bound elements are less significant then the discursive differences between texts of different genres.

\subsection{Russian Culture-Bound Lexicon}

Another point deserving consideration is the contextual functions of Russian culture-bound lexicon in the English-speaking media discourse.

Linguo-cultural analysis of Russian culture-bound lexicon in British and American political discourse shows that the words of Russian origin relating to Russian socio-cultural realities are usually found in the texts that are routinely written by foreign reporters working in the Russian linguo-cultural environment (see Table 1 and Table 2).

Let us provide some examples of specific lexical units that add up to the Russian culture and its intrinsic national character according to the journalists' opinion: the novelty matryoshka dolls; the dozy, ungrateful, narod; the party's babushkas swoon; the modern equivalent of the yurodivy - the creative intelligentsia. It stands to reason that certain "intrusions" of the Russian flavour into the English language fulfil emotional and expressive 
functions, providing enhancements which would otherwise be interpreted differently and revealing attitude to Russian culture and Russian realities, the stereotypical perception of Russia in the West. These texts provide additional evidence where the Russian culture will be no less native for the English speaker, given the great culture and history of the two countries.

Having focused on the functions of Russian culture-bound lexicon in GB and U.S.A. media, we tried to construct a systematic approach to deal with the Russian vocabulary used in the English-speaking discourse about Russia to arrive at the following lexical units:

1). Russian words went international (czar, patriarch, Bolshevik, intelligentsia, vodka).

2). Overall lexical units often found world-wide in Russian news, no trouble for a foreign reader (the Kremlin, the Duma, Putin).

3). Words denoting concepts or objects familiar to British or American speakers, often found in the Russian language in different connotative contexts (narod, babushka, Moroz), yet included in the English text with no translation. This assumes that the English speaker would somehow tell the difference, but it is never guaranteed.

4). Non-equivalent lexicon denoting particular set-ups in Russia, lacking any analogues in the English-speaking world to even approach any wording due to cultural differences, and used by the English author to glue up "a national colour" (yurodivy, krysha, matryoshka, carousel voting). These are commonly provided with well-to-do explanations directly in the body of the text or somewhere around, e.g., yurodivy, a holy fool licensed to speak truth to power; carousel voting is voting where voters are bused to multiple polling stations to vote again and again; the word krysha - literally, means "roof" in Russian but carries a kaleidoscope of other associations: an arrangement; lobbying; political services; icebreaking; protection from murder by Chechen terrorists and bandits; fixing; and a long-term relationship with more or less regular payments.

Another issue is a vast layer where individual lexical units denote something borrowed from the Communist or Post-Communist era (zek, gulag, KGB, siloviki, apparatchiki). These units usually include two or three words, each meant to iconify the USSR or to create post-mortem all-Russian myths with a clear ideological pattern behind, e.g., the heavy KGB hand, a truculent but banal KGB view of the world, the mouldy bun of the Soviet history, looming Stalinist headquarters, Yeltsin's drunken days.

5). No antroponym and toponym found in this paper should dwell on something other than natural events or people to decipher Russian life. These units are all known, un-expendable, and hardly need any decryption: for example, Mr. Navalny, an anticorruption crusader, Kseniya Sobchak, a glamour girl and television hostess; Boris Berezovsky, the former Kremlin insider turned political exile who is now Moscow's biggest headache; Mr. Surkov, the former Kremlin "grey cardinal". Note that such interpretation is often linked to Russian stereotypes that have a clearly negative connotation in the West: Chukotka, a frozen province in Russia's remote Far East; Ramzan Kadyrov, a satrap who knows which side his black bread is buttered on; the thuggish leader of Chechnya, who is known for collecting luxury cars; the rampantly nationalist pro-Kremlin youth group Nashi; Mr. Churov, who is detested by liberals for his alleged role in election fraud. The above is readily explained using culture-specific units such as Ilya Ponomaryov, an MP and protest coordinator; Roman Abramovich, the billionaire owner of Chelsea FC; Pussy Riot; an anti-Putin female punk rock group.

Yet, a host of ideology-driven factors does exist; these will hardly need any translation to enter the English-speaking world. It is most easily seen in the use of non-equivalent vocabularies (both at the world selection layer an in comments/interpretations if any) and, as a matter of fact, may be readily traced in other groups we have identified. In particular, the use of narod with no translation (group 3) implies and emphasises a connotative distinction of this term from its English equivalent, people.

This being said, the mind of an average English reader will always receive a stereotypical Russian image, the image of a frozen country with no way out (Russia has no roads, only directions) abound with dumb morons, female (blonde Russian women) or male (the murky 90s) alike, with Berezovskys (Russia's mega-rich, superwealthy elite), corrupt yet well-to-do pro-Putin's garcons (corrupt and murderous officials), embezzling and bribery staff at all levels (predatory bureaucrats, Soviet era bureaucratic baggage), the almighty securities (KGB cronies) and bloody butchers (thuggish satraps) with their bosses behind (the heavy hand of the Kremlin), - on the one hand, and on the other hand: an imbecile (the dozy, ungrateful narod) trying to behave as his western friends (in a quintessentially Russian passive/aggressive tone), consuming tons of indigestible alcohol (the country's dirt cheap vodka) and judging an opponent as far as he's way too tough for him (the Russians respect only boldness and strength). 


\section{Conclusion}

The results indicate that although Russian narrative fails to occupy the dominant position in the political discourse of the United Kingdom and the United States (as follows from the analysis of article placement and their division into thematic areas), Russia is internationally covered and represented in a comprehensive and detailed manner (which is demonstrated by the analysis of the cultural context), so it should by no means be regarded as a periphery topic. Moreover, the content analysis of Russia's portrayal in British and U.S.A. media political discourse has shown that the discourse about Russia is deeply integrated into the cultural context of the English-speaking audience; it can be said that Russia's image in the Anglophone political media discourse is outlined with the aid of various cultural-bound associative, connotative and metaphorical links which are familiar for native readers and serve them as a bridge facilitating their understanding and interpretation of the "other", relatively unknown and remote culture. On the one hand, it contributes to a deeper, clearer and more emotional perception of Russian realities; on the other hand, the integration of information in the cultural context provides the reader with unambiguous algorithms for interpreting this information, sometimes imposing the author's opinion on the topic which might be stereotypical or biased.

The analysis of Russian cultural-bound lexical items which were used in the studied articles devoted to Russia allows us to put forward an assumption that their authors' intention was to create a bright, full and colourful image of Russia rather than one-dimensional representation. However, such representations sometimes lack objectivity and are to some extent stereotypical, corresponding to readers' perception of Russian reality.

Finally, we should like to note that we have found no essential distinctions in either British or American press as to a "stereotype image of the Russian society". In other words, both the U.S.A. and the Great Britain have built a solid linguo-cultural platform their citizens have no chance to jump off when it comes to Russia. Nevertheless, discussions of Russian events in this linguo-cultural community can not be called one-sided: naturally, mass media are trying to capture various positions, views and relations, but their differences do not pertain to countries but rather to the types of media texts, to political platforms of publishers, etc. This confirms that the studies we have completed should have made distinctions between news, analytical and journalistic texts rather than British or American materials where such distinctions are basically non-essential.

\section{Acknowledgements}

The publication was prepared with the support of the "RUDN University Program 5-100".

\section{References}

Akhmanova, O. S. (2004). Dictionary of Linguistic Terms. Moscow, Russia: Editorial URSS.

Belova, O. (2016). The Challenge of Reset. A Discourse Analysis of Barack Obama's Construction of Russia in 2009-12. Journal of Language and Politics, 15(6), 748-767. https://doi.org/10.1075/jlp.15.6.05bel

Cap, P. (2013). Proximization. The Pragmatics of Symbolic Distance Crossing. Amsterdam: John Benjamins.

Chilton, P. (2004). Analyzing Political Discourse: Theory and Practice. London, England: Routledge.

Chudinov, A. P. (2001). Russia in a Metaphorical Mirror: Cognitive Research of the Political Metaphor (1991-2000) / Rossiya v metaphoricheskom zerkale: kognitivnoye issledovaniye politicheskoy metaphory (1991-2000). Ekaterinburg, Russia: UrGPU. Retrieved from http://www.philology.ru/linguistics2/chudinov-01.htm

Dobrosklonskaya, T. G. (2008). Medialinguistics: The System Approach to the Study of Mass Communicaton Language. Moscow: Flintar $\quad$ Retrieved from http://www.ffl.msu.ru/research/publications/dobrosklonskaya/dobrosklonskaya-medialingvistika.pdf

Dubrovskaya, T., \& Kozhemyakin, E. (2017). Media Construction of Russia's International Relations: Specifics $\begin{array}{lllll}\text { of Representations. Critical Discourse } & \text { Studies, } & \text { 14(1), }\end{array}$ http://dx.doi.org/10.1080/17405904.2016.1196228

Fairclough, N. (1995). Media Discourse. London, England: Edward Arnold.

Fairclough, N. (2001). Language and Power (Language in Social Life). London, England: Routledge.

Feklyunina, V. (2008). Battle for perceptions: Projecting Russia in the West. Europe-Asia Studies, 60(4), 605-629. http://dx.doi.org/10.1080/09668130801999888

Ivanovic, I. (2017). Comparative Study of Metaphor in British and United States of America (US) Political Discourse. XLinguae Journal, 10(2), 16-29. https://doi.org/10.18355/XL.2017.10.02.02 
Kabel, L. (2017). The Coverage of Russia by the Danish Media. Denmark, NJC: Ajour. Retrieved from https://www.ucviden.dk/portal/files/41322310/Russia_report_English_pdf.pdf

Kopytowska, M. (2015). Covering Conflict: Between Universality and Cultural Specificity in News Discourse, Genre and Journalistic Style. International Review of Pragmatics, 7(2), 308-339. http://dx.doi.org/10.1163/18773109-00702007

Macgilchrist, F. (2011). Journalism and the Political: Discursive Tensions in News Coverage of Russia. Amsterdam: John Benjamins Publishing Company.

Maximova, O., \& Egorova, M. (2016). Linguistic and Cultural Characteristics of Russian Political Blogosphere. Advances in Social Sciences, Education and Humanities Research, 40, 293-296. Proceedings of the 3rd International Conference on Education, Language, Art and Inter-cultural Communication (ICELAIC2016). Xiamen, China. http://dx.doi.org/10.2991/icelaic-16.2017.73

Moscovici, M. (2012). Russia's Portrayal in the Western Media: A Quantitative Analysis of Leading Media Agency News Stories in 2007. Arlington: The University of Texas at Arlington Press. Retrieved from https://pdfs.semanticscholar.org/1ebe/f9672e2e82865725244c89541e30db9ef6f0.pdf

Nunan, D. (1993). Introducing Discourse Analysis. London, England: Penguin.

Shapieva, D. Z. (2013). Metaphorical Representation of Russia in the Political Discourse of Anglophone Mass Media. Russian Journal of Linguistics (Bulletin of Russian Peoples' Friendship University. Series Linguistics), 2, 51-58. Retrieved from http://journals.rudn.ru/linguistics/article/view/9711/9162

Sokolova, F. H., \& Koptyaeva, A. A. (2015). Modern Political Image of Russia in Norway (on Media Coverage). Arctic and North, 18, 81-94. http://dx.doi.org/10.17238/issn2221-2698.2015.18.81

Solopova, O. A., \& Ilyushkina, M. Y. (2017). Russia as a Target Domain in American, British and Canadian Political Discourses. Bulletin of the South Ural State University. Series Linguistics, 14(3), 41-48. http://dx.doi.org/10.14529/ling170306

Telesheva, I., \& Denisova, I. (2015). The Evolution of the Russian Image in the English Discourse. Procedia-Social and Behavioral Sciences. Part of special issue: The Proceedings of 5th World Conference on Learning, Teaching and Educational Leadership, 186, 1025-1030. https://doi.org/10.1016/j.sbspro.2015.04.065

Tsygankov, A. (2016). The Dark Double: American Media Perception of Russia as Neo-soviet Autocracy, 2008-2014. Politics, 37(1), 19-35. https://doi.org/10.1177/0263395715626945

van Dijk, T. A. (2001). Critical Discourse Analysis. In D. Schiffrin, D. Tannen, \& H. E. Hamilton (Eds.), The Handbook of Discourse Analysis (pp. 352-371). Oxford, England: Blackwell.

van Dijk, T. A. (1985). Structures of News in the Press. In T. van Dijk (Ed.), Discourse and Communication (pp. 69-93). Berlin, Germany: de Gruyter.

van Dijk, T. A. (1988). The Analysis of News as Discourse. In T. van Dijk (Ed.), News Analysis. Case Studies of International and National News in the Press (pp. 1-30). Hillsdale, NJ: Lawrence Erlbaum.

van Dijk, T. A. (2006). Discourse and Manipulation. Discourse \& Society, 17(2), 359-383. https://doi.org/10.1177/0957926506060250

Vraciuu, M. (2012). Russia (n) in Context: Aspects of Metaphor in the Russian Political Discourse. International Journal of Communication Research, 2(4), 310-324. Retrieved from http://www.ijcr.eu/articole/99_38_pdfsam_IJCR\%204-2012\%20tipo.pdf

\section{Note}

Note 1. The sites of newspapers and blogs used in the study:

Brendan O'Neil's blog: http://www.telegraph.co.uk/authors/brendan-oneill/

David Blair's blog: http://www.telegraph.co.uk/journalists/david-blair/

The Daily Telegraph: http://www.telegraph.co.uk/

The Guardian: http://www.guardian.co.uk/

The Independent: http://www.independent.co.uk/

The New York Post: http://www.nypost.com/ 
The New York Times: http://global.nytimes.com/

The Times: http://www.thetimes.co.uk/tto/news/

\section{Copyrights}

Copyright for this article is retained by the author(s), with first publication rights granted to the journal.

This is an open-access article distributed under the terms and conditions of the Creative Commons Attribution license (http://creativecommons.org/licenses/by/4.0/). 